\title{
Biochemical properties of renin and prorenin binding to the (pro)renin receptor
}

\author{
AHM Nurun Nabi and Fumiaki Suzuki
}

The discovery of (pro)renin receptor, (P)RR, has made the renin-angiotensin system (RAS) more multifaceted. Interaction of renin and prorenin with this receptor has set a new perspective about the physiological functions, activation mechanism and pathophysiological roles of renin/prorenin. Uses of peptides mimicking the structure of the ligands have been very effective for determining structure-function relationship between the ligands and receptor. The probable pivotal role of decoy peptide region ( ${ }^{10 P}$ IFLKRMPSI ${ }^{19 P}$ ) of prorenin prosegment was suggested for higher binding affinity of prorenin to (P)RR than that of mature renin. Recently, 'hinge' region peptide $\left(S^{149} Q G V L K E D V F{ }^{158}\right)$ in renin/prorenin molecule has been reported. Both renin and prorenin can interact with (P)RR through the 'hinge' region. Furthermore, it has been proposed that prorenin has multiple binding sites whereas renin has a single binding site for (P)RR. To comprehend the activation mechanism of renin and prorenin after receptor binding, it is very important to understand their interaction with the receptor. Several kinds of peptides designed from the regions of the tertiary structure of renin and predicted model of prorenin facilitated the study of the in vitro binding mechanisms for renin and prorenin to (P)RR. Here, a series of recent in vitro studies was reviewed to discuss a possible binding mechanism of renin/prorenin to the (P)RR.

Hypertension Research (2010) 33, 91-97; doi:10.1038/hr.2009.201; published online 27 November 2009

Keywords: decoy peptide; ‘handle' region peptide; 'hinge' region peptide; (pro)renin receptor; (P)RR blocker

\section{INTRODUCTION}

The renin-angiotensin system (RAS) has been accredited for the regulation of blood pressure and electrolyte balance ${ }^{1-4}$ and thus can trigger cardiovascular-related disorders. Renin is the rate-limiting enzyme in RAS. This enzyme is secreted into the blood stream only from the juxtaglomerular cells of the kidney in response to cellular stimuli. ${ }^{5,6}$ On the other hand, prorenin, the inactive precursor of renin, has been found to synthesize not only in the juxtaglomerular cells but also in many other tissues such as the collecting duct, adrenal, zona glomerulosa, eye, Müller cells, mast cells, ovary, thecal cells, uterus, myometrium/decidual cells, placenta, chorionic cells, testis and Leydig cells, and submandibular gland. ${ }^{7}$ Prorenin is secreted from these tissues into the blood constitutively ${ }^{5,6,8}$ and its level in the circulation is 10 times higher than that of mature renin. ${ }^{9,10}$ The precursor of renin is inactive, because the prosegment region with 43 amino acid residues covers the active site of renin with 339-341 residues. ${ }^{11-15}$ Activation of prorenin can take place either proteolytically or non-proteolytically. Proteolytic activation has been observed in vitro by treatments of some proteases, ${ }^{16-21}$ thereby, irreversibly removing the prosegment. The non-proteolytic activation of prorenin has been shown under acidic $\mathrm{pH}$ or low temperature (cryo-activation) that reversibly altered the stereo structure of intact prorenin molecule into a catalytically active form..$^{22,23}$ Also, the 'gate' $\left(\mathrm{T}^{7 \mathrm{P}} \mathrm{FKR}^{10 \mathrm{P}}\right)$ and 'handle' $\left(\mathrm{I}^{11 \mathrm{P}} \mathrm{FLKR}^{15 \mathrm{P}}\right)$ regions in the prorenin prosegment were indicated in vitro to be accountable for the non-proteolytic activation of prorenin molecules through protein-protein interaction. ${ }^{24}$ The (pro)renin receptor, ${ }^{25}$ (P)RR, a new player in the RAS components, binds both renin and prorenin. ${ }^{25-29}$ The (P)RR itself has been observed to be associated with many pathophysiology of diseases. ${ }^{30-35}$ Considering the physiological importance of the $(\mathrm{P}) \mathrm{RR}$, this review is focused on the studies regarding the binding mechanism of renin/prorenin to $(\mathrm{P}) \mathrm{RR}$ on the basis of their biochemical aspects.

\section{THE INTERACTION OF RENIN/PRORENIN WITH THE (P)RR}

(Pro)renin receptor binds renin, thereby locally increases angiotensin production. ${ }^{25}$ It is interesting to note that this receptor has also been found to activate prorenin. ${ }^{25-29}$ After binding to the (P)RR, prorenin undergoes a conformational change in the prosegment region, thus opening the active site accessible to the substrate angiotensinogen (Figures 1 and 2). The (P)RR mRNA has been reported to express in many organs, for example the kidney, heart, brain, eye, adipose tissue and vascular smooth muscle cells, ${ }^{25,34}$ and thus it may help to accumulate renin and prorenin locally in tissues even though lacking components of RAS, that is, in the heart and vasculature wall. $^{36,37}$ Therefore, receptor-associated both renin and prorenin have been proposed to potentially activate tissue-specific RAS in an angiotensin-II-dependent manner (Figure 1). As plasma prorenin 


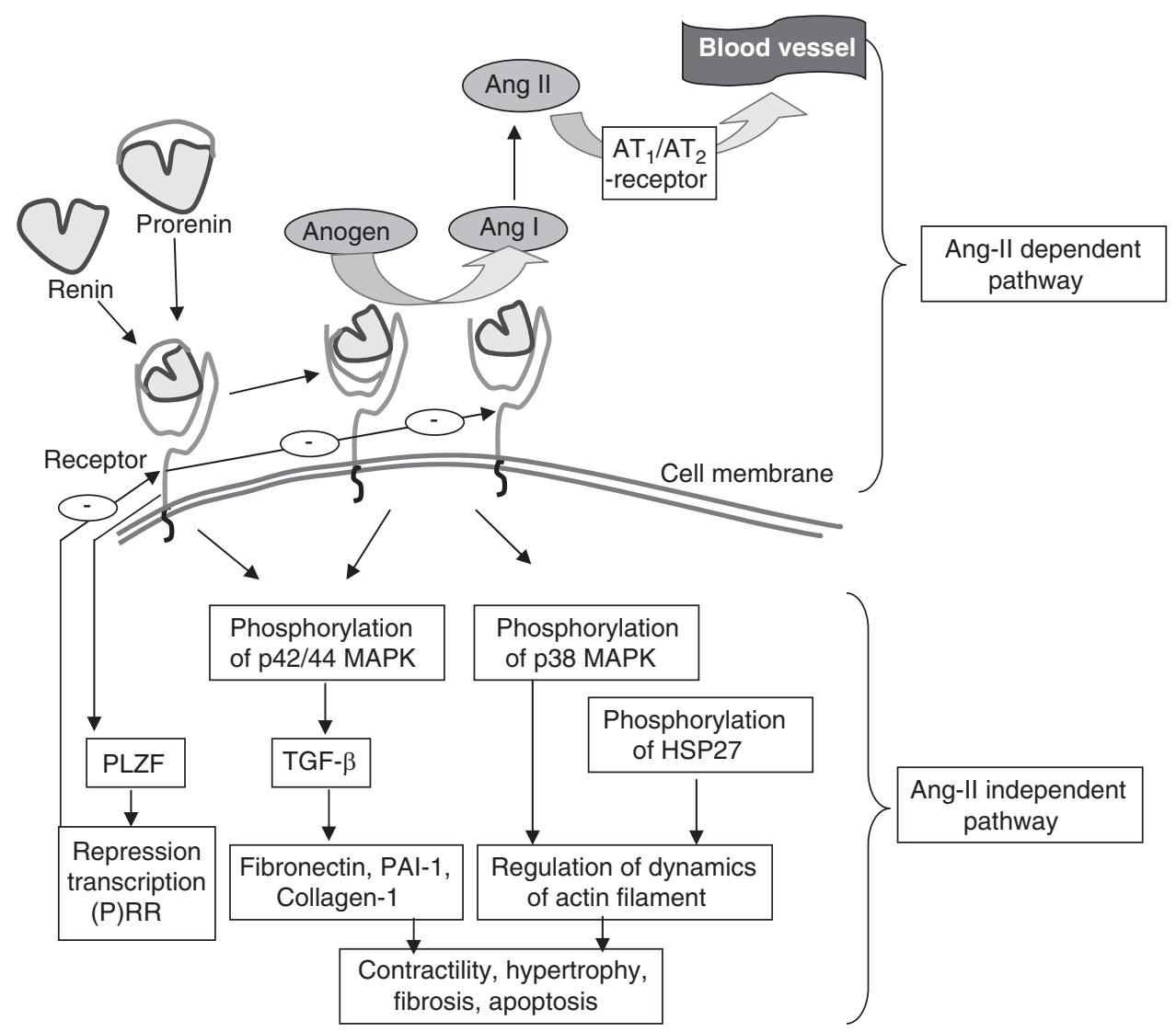

Figure 1 Renin-angiotensin system (RAS)-dependent and -independent pathways mediated by renin and prorenin associated with the (pro)renin receptor, (P)RR. After binding to the receptor, renin/prorenin carry out their functions either in angiotensin-II-dependent or -independent pathways that may facilitate the generation of angiotensin-I or activation of second messenger, respectively. This implies that renin/prorenin act as agonist independent of angiotensin generation. Anogen, angiotensinogen; Ang-I, angiotensin-I; Ang-II, angiotensin-II; PLZF, promyelocytic leukemia zinc finger; PAI-1, plasminogen activator inhibitor-1; TGF- $\beta$, transforming growth factor; HSP, heat-shock protein; MAPK, mitogen activated protein kinase.

level is higher than renin, thus it is suggested that prorenin may have a major role in this regard. Moreover, such demonstration of catalytic activity of prorenin could explain prorenin-induced pathological effects in diabetic patients, where prorenin represent $\leqslant 95 \%$ of total circulating renin ${ }^{38}$ and could develop and progress nephropathy in diabetic animals with high plasma levels of prorenin. ${ }^{35}$

Further, binding of renin and prorenin to the receptor possibly triggers their own intracellular signaling pathways independent of RAS (Figure 1). Both renin and prorenin stimulated p42/p44 mitogenactivated protein kinase (MAPK) activation and transforming growth factor- $\beta 1$ release in mesangial cells in the presence of renin and ACE inhibitors and/or $\mathrm{AT}_{1}$ receptor antagonists. ${ }^{25,39}$ Moreover, prorenin also activated p38 mitogen-activated protein kinase and simultaneously phosphorylate heat-shock protein 27 in cardiomyocytes. ${ }^{40}$ Prorenin stimulated extracellular signal-related protein kinase phosphorylation through (P)RR-mediated activation of tyrosine kinase. ${ }^{41}$ Schefe et al. ${ }^{42}$ reported the transcription factor promyelocytic leukemia zinc-finger protein as a direct protein interaction partner of the C-terminal domain of the $(\mathrm{P}) \mathrm{RR}$, which is translocated into the nucleus and represses transcription of the (P)RR itself, thereby creating a very short negative feedback loop.

\section{BINDING PROPERTIES OF RENIN AND PRORENIN TO THE (P)RR}

The schematic representation of the binding properties of renin and prorenin to the recombinant (P)RR has been shown in Figure 2.
We observed higher binding affinity of rat prorenin for the $(\mathrm{P}) \mathrm{RR}$ compared with that of rat renin molecule in vitro using rat recombinant (P)RR expressed in the baculovirus expression system. ${ }^{26,43}$ Their values of equilibrium dissociation constant $\left(K_{\mathrm{D}}\right)$ were 8.0 and $20.0 \mathrm{nmoll}^{-1}$, respectively (Figure $2 \mathrm{a}$ ). Rat prorenin was also activated by receptor binding. The values of $K_{\mathrm{m}}$ (Michaelis constant) of renin and active prorenin, for the substrate sheep angiotensinogen, indicated that even after binding to $(\mathrm{P}) \mathrm{RR}$, both renin and prorenin had similar $K_{\mathrm{m}}$ value at $3.3 \mu \mathrm{moll}^{-1}$. As $K_{\mathrm{m}}$ decreases, the enzyme's (renin) affinity for the substrate (angiotensinogen) increases. On the other hand, receptor-bound renin had higher molecular activity $\left(10 \mathrm{nmoll} \mathrm{h}^{-1}\right)$ compared with the free form of mature renin and receptor-bound activated prorenin $\left(1.25\right.$ and $\left.1.1 \mathrm{nmollh}^{-1}\right) .^{26}$

In addition, $90 \%$ of rat prorenin (at $2.0 \mathrm{nmoll}^{-1}$ of initial concentration) bound to (P)RR overexpressed on the membrane of COS7 cells and the $K_{\mathrm{D}}$ was estimated $0.89 \mathrm{nmoll}^{-1}$ (Figure 2c). ${ }^{29}$ The $K_{\mathrm{m}}$ value of receptor-bound activated prorenin was $1.0 \mu \mathrm{moll}{ }^{-1} .{ }^{29}$ Differences in the $K_{\mathrm{D}}$ values of rat prorenin bound to the immobilized receptors on the synthetic surfaces and the membrane-anchored receptor could be because of the presence of some other associated proteins that might have stabilized the $(\mathrm{P}) \mathrm{RR}$ on the membrane.

We also showed that overexpressed human (P)RRs could bind $50 \%$ of human prorenin (when initial concentration of prorenin was set at $2.0 \mathrm{nmoll}^{-1}$ ). The $K_{\mathrm{D}}$ was determined at $1.8 \mathrm{nmoll}^{-1}$ (Figure 2c). ${ }^{29}$ Receptor-bound rat and human prorenin showed 30 and $40 \%$ activity, respectively, in comparison with the activity of trypsinized prorenin 


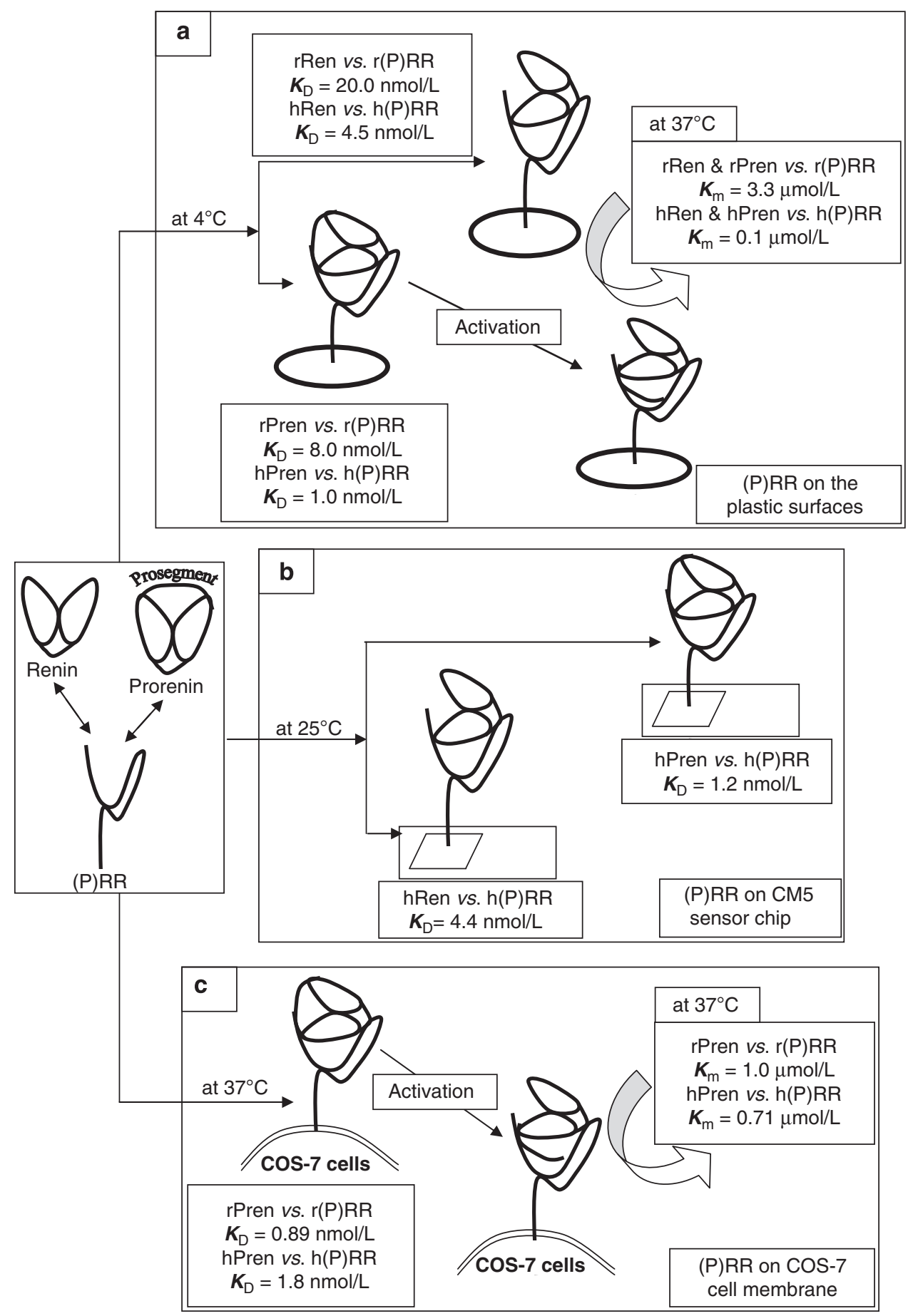

Figure 2 Schematic diagram for the in vitro binding properties of renin and prorenin molecules to the immobilized (pro)renin receptor, (P)RR. Binding experiments of these molecules were carried out using immobilized receptors at different conditions for example, (a) at $4^{\circ} \mathrm{C}$ on the synthetic plastic surfaces, ${ }^{26,44,45}$ (b) at $25^{\circ} \mathrm{C}$ on the CM5 sensor chip for BIAcore analyses ${ }^{44,45}$ and (c) at $37^{\circ} \mathrm{C}$ on the COS-7 cell membrane. ${ }^{29}$ Angiotensin-I generation mediated by the receptor-bound renin and active prorenin (through local conformational change after receptor binding) at $37^{\circ} \mathrm{C}$ and measured by the standard Ang-I ELISA. ${ }^{26,29,45}$ Both rat and human renin/prorenin bound to their respective receptors at different conditions with different values of the dissociation constant $\left(K_{D}\right)$, whereas prorenin showed three to four times higher binding affinity for the receptor compared with that of mature renin at each binding condition used. rRen, rat renin; rPren, rat prorenin; r(P)RR, rat (pro)renin receptor; hRen, human renin; hPren, human prorenin; h(P)RR, human (pro)renin receptor.

molecules. Batenburg et al. ${ }^{27}$ found a similar activation of human prorenin by binding to the human (P)RR with $6.0 \mathrm{nmoll}^{-1}$ of $K_{\mathrm{D}}$, using the receptor expressed in smooth muscle cells of transgenic rat for this receptor. Zhang et al. ${ }^{28}$ reported the activation of rat prorenin after binding to rat (P)RR expressed in the cultured vascular smooth muscle cells.

By surface plasmon resonance technique in BIAcore assay system (Figure 2b), we further confirmed that human prorenin molecule has 


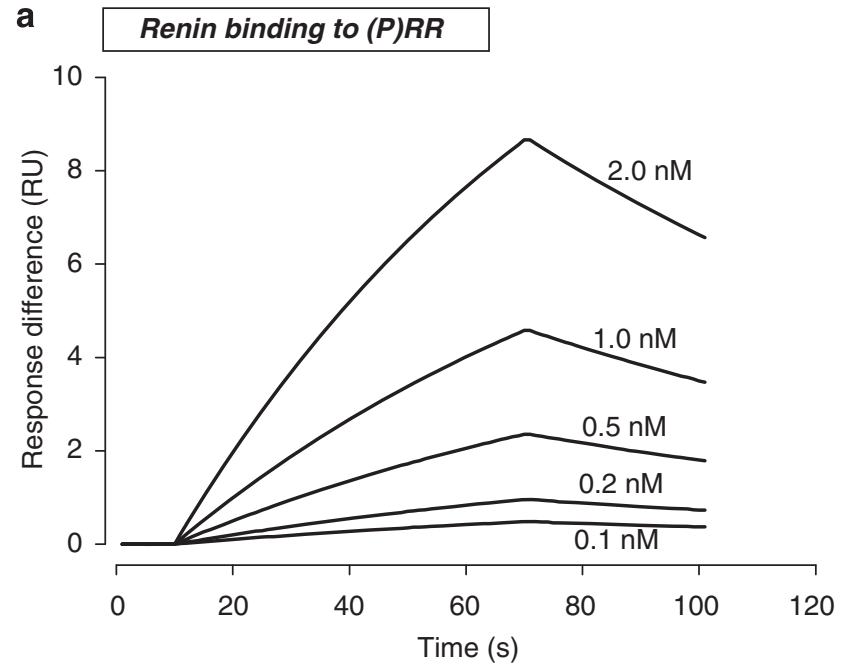

b

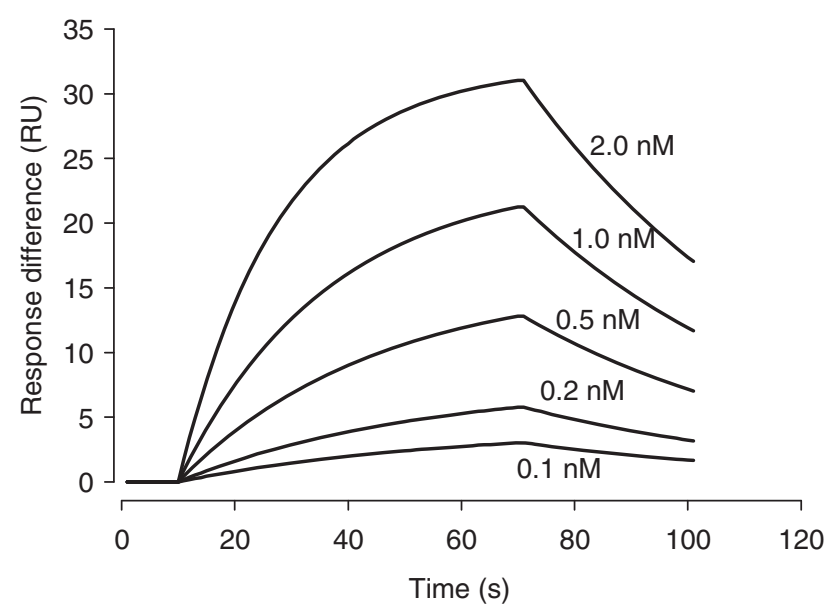

Figure 3 Binding of renin and prorenin to the immobilized receptor using the surface plasmon resonance (SPR) technique. Method for the immobilization of the recombinant human (pro)renin receptor, $h(P) R R$, has been described by Nabi et al. ${ }^{44,45}$ Figures (a) and (b) represent the typical binding curves for renin and prorenin to (P)RR, respectively constructed using the association and dissociation rate constants by BIAsimulation. These curves were evaluated and the dissociation constants $\left(K_{D}\right)$ for the binding of renin and prorenin to the receptor were estimated at 4.4 and $1.2 \mathrm{nmol} \mathrm{I}^{-1}$, respectively. ${ }^{44}$

four times higher binding affinity for the human recombinant (P)RR than human mature renin. ${ }^{44,45}$ The purified recombinant human (P)RR expressed in a cell free in vitro system was immobilized on the surfaces of the CM5 sensor chip as described previously. ${ }^{44,45}$ Figures $3 \mathrm{a}$ and $\mathrm{b}$ show the bindings of recombinant renin and prorenin to the immobilized $(\mathrm{P}) \mathrm{RR}$ derived from the BIAsimulation software and the $K_{\mathrm{D}}$ values were determined to be 1.2 and $4.4 \mathrm{nmoll}^{-1}$, respectively. Also, the data obtained from the BIAcore kinetic study showed that the association rate of prorenin to $(\mathrm{P}) \mathrm{RR}$ is higher than that of mature renin $\left(1.8 \times 10^{7}\right.$ and $2.16 \times 10^{6} \mathrm{M}^{-1} \mathrm{~s}^{-1}$, respectively). ${ }^{44,45}$

\section{HRP/DECOY AND 'HINGE' REGION PEPTIDES ARE THE MOST PROBABLE CANDIDATES FOR (P)RR BLOCKER}

The decoy peptide mimics the $\mathrm{R}^{10 \mathrm{P}}$ IFLKRMPSI ${ }^{19 \mathrm{P}}$ region of prorenin prosegment was first indicated by Ichihara et al..$^{30}$ who designed this peptide based on the 'handle' region peptide (HRP, $\mathrm{I}^{11 \mathrm{P}} \mathrm{FLKR}{ }^{15 \mathrm{P}}$ ) in prorenin prosegment reported by Suzuki et al. ${ }^{24}$ Ichihara et al. ${ }^{30}$ demonstrated complete inhibition of diabetic nephropathy by administering this peptide in the streptozotocin-induced diabetic rats. After that, many in vivo studies have investigated the effective use of the decoy containing 'handle' region peptide as (P)RR blocker and confirmed the regression of established diabetic nephropathy in heminephrectomized streptozotocin-induced diabetic rats; ${ }^{46}$ attenuation of the development and progression of proteinuria and glomerulosclerosis and reduction of renal angiotensin levels in stroke-prone spontaneously hypertensive rats without an effect on blood pressure; ${ }^{47}$ attenuation of cardiac fibrosis in spontaneously hypertensive rats fed on a high-salt diet. ${ }^{48}$ Rat HRP also reduced the action-potential frequency in rat brain. ${ }^{49}$ Human HRP prevented the proteinuria and glomerulosclerosis that developed in human (P)RR transgenic rats. ${ }^{31}$ Blockade of prorenin activation using decoy peptide in spontaneously hypertensive rats with high-salt diet has been reported by Susic et al., ${ }^{50}$ who also showed reduction of serum creatinine level, decreased left ventricular mass and fibrosis, improved left ventricular function by treating these rats with the decoy.

In vitro study also showed that both decoy and 'handle' region peptides from rat and human inhibited the bindings of rat and human prorenins to their respective $(\mathrm{P}) \mathrm{RR}$ on the membrane over expressed in COS-7 cells, with a $K_{\mathrm{i}}$ of $6.6 \mathrm{nmoll}^{-1}$. $^{29}$ Moreover, human HRP prevented prorenin-induced activation of extracellular signal-related protein kinase $1 / 2$ in COS-7 cells expressing the $h(P) R R,{ }^{30}$ rat HRP decreased not only mesangial cell proliferation but also the expression of transforming growth factor- $\beta 1$ mRNA and phosphorylation of extracellular signal-related protein kinase $1 / 2 .^{51}$ Also, HRP inhibits the development of retinal neovascularization through interfering non-proteolytic activation of prorenin in experimental retinopathy model of prematurity. ${ }^{52}$ Satofuka et al., ${ }^{53,54}$ using the same model, showed that the HRP suppressed the pathological angiogenesis, leukocyte accumulation and intracellular adhesion molecule-1 with vascular endothelial growth factor expression; reduced retinal gene and protein expression of inflammatory mediators.

On the contrary, other investigators reported that HRP/decoy peptide affected neither prorenin binding to $(\mathrm{P}) \mathrm{RR}$ expressed on the vascular smooth muscle cells nor Ang-I generation, ${ }^{27}$ it could not block prorenin- and renin-induced extracellular signal-related protein kinase $1 / 2$ activation through (P)RR in monocytes, ${ }^{38}$ it had no effect on hypertensive nephrosclerosis in Goldbatt rats ${ }^{55}$ and HRP failed to show its effect on prorenin transgenic mice. ${ }^{56} \mathrm{~A}$ few of them have also suggested a different mode of action of the HRP other than (P)RR blocking and thus, disregarding the possibility of HRP binding to (P)RR. The major differences regarding the HRP/decoy hypothesis in the context of clinical studies are still to be explained. The probable explanation could be the differences in the experimental approaches used along with the doses of the peptides, and of the variation among the physiological conditions of the experimental model animals and/ or their species. ${ }^{27,30,38,49-51,53-56}$

These incompatible results with decoy peptide containing HRP have led us to further investigate the effects of decoy peptide on the binding of renin/prorenin to (P)RR in vitro. We found that not only renin/prorenin but also the decoy containing HRP directly bound to the recombinant $(\mathrm{P}) \mathrm{RR}$ as shown in Figure $4 \mathrm{a}$ and Table 1 . The binding experiments with other peptides designed from the predicted tertiary structure of prorenin prosegment for example, $\mathrm{L}^{1 \mathrm{P}} \mathrm{PTD}^{4 \mathrm{P}}$ $\mathrm{L}^{1 \mathrm{P}} \mathrm{PTDTTTF}^{8 \mathrm{P}}$ and $\mathrm{L}^{1 \mathrm{P}} \mathrm{PTDTTTFKRIFLKR}{ }^{15 \mathrm{P}}$ were also carried out and their $K_{\mathrm{D}}$ values were determined as $3.19 \times 10^{4}, 52$ and $7.56 \mathrm{nmoll}^{-1}$, respectively. ${ }^{44,45}$ These data unveil the fact that 

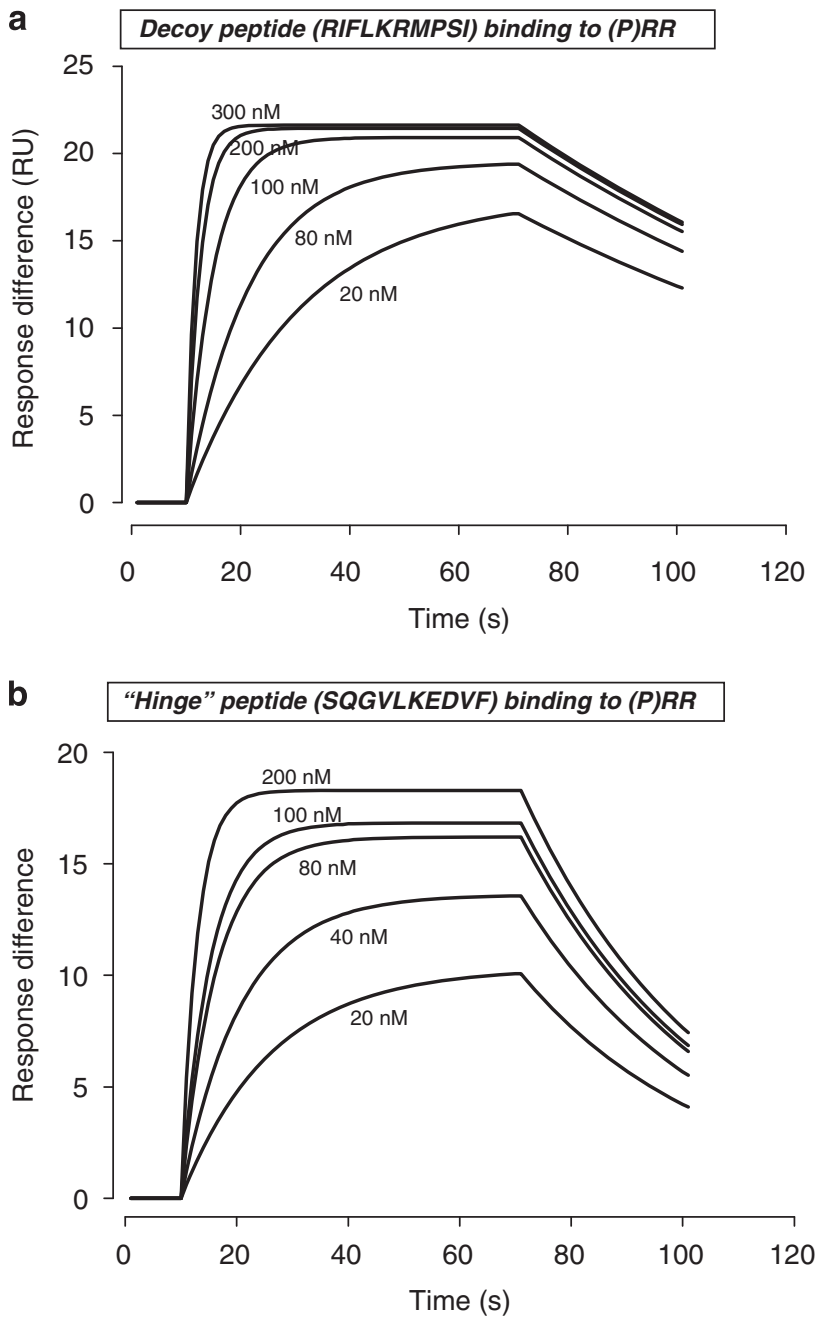

Figure 4 Direct binding of decoy and 'hinge' peptides to the immobilized receptor using surface plasmon resonance (SPR) technique in BIAcore assay system. Figures (a) and (b) represent the typical binding curves for the decoy ( $\mathrm{R}^{10 P}$ IFLKRMPSI $^{19 P}$ ) and a new 'hinge' $\left(\mathrm{S}^{149} \mathrm{QGVLKEDVF}^{158}\right)$ region peptides to the (pro)renin receptor, (P)RR, respectively, constructed using the association $\left(k_{\mathrm{a}}\right)$ and dissociation $\left(k_{\mathrm{d}}\right)$ rate constants by BIAsimulation. These curves were evaluated and the dissociation constants $\left(K_{\mathrm{D}}\right)$ for the binding of these peptides to the receptor were 3.5 and $17.0 \mathrm{nmoll}^{-1}$, respectively. 44,45

Table 1 Dissociation constants $\left(K_{\mathrm{D}}\right)$ for complexes of various kinds of peptides with (pro)renin receptor, $(P) R^{44,45}$

(P)RR associated with anti-221/235 antibody

Peptide

$L^{1 P P T D} 4 \mathrm{P}$

$L^{1 P P T D T T T F}{ }^{8 P}$

LIPPTDTTTFKRI $^{11 P}$ FLKR $^{15 P}$

$\mathrm{R}^{10 \mathrm{P}^{11 P}}$ FLKR $^{15 \mathrm{P}_{\text {MPSI }}{ }^{19 P} \text { (decoy peptide) }}$

$\mathrm{A}^{248}$ KKRLFDYVV257

$\mathrm{S}^{149}$ QGVLKEDVF ${ }^{158}$ ('hinge' region peptide)

I11PFLR $^{15 P}$ : 'handle' region peptide.
$\mathrm{I}^{11 \mathrm{P}} \mathrm{FLKR}^{15 \mathrm{P}}$-containing sequence show higher binding affinity for the receptor (Table 1). Also, when the decoy was co-incubated with prorenin and flown at a rate of $10 \mu \mathrm{min}^{-1}$, reduction of resonance units in the BIAcore sensogram clearly indicated binding inhibition of prorenin to (P)RR by the peptide. It is interesting to note that decoy peptide also inhibited binding of renin to $(\mathrm{P}) \mathrm{RR}$. The decoy inhibited the renin and prorenin binding competitively with the $K_{\mathrm{i}}$ of 16.7 and $15.1 \mathrm{nmoll}^{-1}$, respectively measured from the equilibrium state analysis. ${ }^{45}$

Thus, these observations revealed that prorenin has higher binding affinity for $(\mathrm{P}) \mathrm{RR}$ compared with that of mature renin and the decoy sequence of the prosegment has been suggested to have an essential role for the prorenin binding. ${ }^{4}$ The decoy binding with high affinity to $(\mathrm{P}) \mathrm{RR}$ explains the probable reason for high-affinity binding of prorenin. The binding inhibition of decoy for renin to (P)RR still remain to be elucidated, as it is lacking the prosegment sequence. Based on these annotations and on the tertiary structure of renin as well as predicted tertiary structure of prorenin, the possibility of having a common site in both renin and prorenin through which these molecules can interact with the $(\mathrm{P}) \mathrm{RR}$ other than the decoy peptide sequence was hypothesized. A new sequence $\left(S^{149}\right.$ QGVLKEDVF $\left.{ }^{158}\right)$ that localizes in the flexible junctional region between the $\mathrm{N}$ - and C-domains of renin/prorenin termed as the 'hinge' has recently been reported to have such pivotal role for renin/prorenin binding to (P)RR. ${ }^{45}$ The $K_{\mathrm{D}}$ for the binding of the 'hinge' peptide to (P)RR was five times higher than that of the decoy and estimated to be $17 \mathrm{nmoll}^{-1}$ (Table 1, Figure $4 \mathrm{~b}$ ). The 'hinge' showed higher binding affinity to the (P)RR than that of another peptide $\left(\mathrm{A}^{248} \mathrm{KKRLFDYVV}{ }^{257}\right)$ from the C-domain of renin/prorenin molecule. Like the decoy, 'hinge' peptide also reduced the resonance signal of renin/prorenin binding to $(\mathrm{P}) \mathrm{RR}$ in the sensogram of BIAcore, and equilibrium state analysis revealed this paradigm as a competitive inhibition with the $K_{\mathrm{i}}$ of 37.1 and $30.7 \mathrm{nmoll}^{-1}$, respectively. ${ }^{45}$ Therefore, these data proclaimed that not only the decoy peptide but also the 'hinge' region peptide together accounted for the higher binding affinity of prorenin and hence, prorenin molecule has at least two sites whereas renin has a single site through which these molecules can interact with the $(\mathrm{P}) \mathrm{RR}$.

\section{EFFECTS OF ALISKIREN, HRP/DECOY AND 'HINGE' PEPTIDES ON RENIN ACTIVITY}

Aliskiren, a new orally direct renin inhibitor, potently inhibits the renin activity and thus lowers angiotensin II generation in vivo. ${ }^{57-59}$ Also, aliskiren bound to the active form of prorenin in vivo. ${ }^{60,61}$ On the other hand, this renin inhibitor did not blunt bindings of renin and prorenin to $(\mathrm{P}) \mathrm{RR}$, whereas it significantly decreased the mRNA expression of $(\mathrm{P}) \mathrm{RR}$ in the kidney cortex of diabetic hypertensive Ren 2 rats. ${ }^{61}$

A peptide like renin inhibitor was first reported by Szelke et al. ${ }^{62}$ Peptides derived from the bovine pepsinogen (17 residues at the $\mathrm{NH}_{2}$-terminus of bovine and 1-16 residues of the porcine pepsinogens) were found to inhibit pepsin activity in a milk clotting assay at pH 5.5 with high values of $K_{\mathrm{i}} \cdot{ }^{63,64}$ Cumin et al. ${ }^{65}$ demonstrated that a peptide which is located in the region corresponding to 9-20 in human renin prosegment inhibited the renin activity. Its $K_{\mathrm{i}}$ value was $500 \mathrm{nmoll}^{-1}$. The $K_{\mathrm{i}}$ value is equivalent to the dissociation constant of enzyme-inhibitor complex. We observed that the renin activity either in the soluble free form or in the receptor-bound state of renin/ prorenin was not inhibited by the decoy $\left(11^{\mathrm{P}}-19^{\mathrm{P}}\right)$ and the 'hinge' (149-158) peptides at $80 \mathrm{nmoll}^{-1} .45$ Thus, both the peptides at range of and/or less than $80 \mathrm{nmoll}^{-1}$ did not have any effect on the catalytic activities of receptor-bound renin and prorenin. Therefore, these 
indicate that the peptides at lower concentration only blunt the interaction of renin/prorenin with the receptor.

\section{INTERFERENCE OF RENIN BINDING TO (P)RR BY THE DECOY} Inhibition of the decoy peptide for prorenin binding to $(\mathrm{P}) \mathrm{RR}$ is understandable. On the other hand, the binding inhibition of the decoy peptide for the renin binding is an anonymity that needs to be clarified. Prorenin binds to $(\mathrm{P}) \mathrm{RR}$ and then it is non-proteolytically activated $^{25,26}$ through local conformational changes at least in the prorenin prosegment. ${ }^{25}$ During this process, not only the prorenin but also the counter parts of prosegment in the receptor must alter into a stable receptor-ligand complex. Such local conformational change should also occur in the (P)RR when the decoy binds to the receptor. Therefore, change in the tertiary structure of the $(\mathrm{P}) \mathrm{RR}$ after interacting with the decoy peptide might be the most probable reason for the inhibition of renin binding by this peptide. Many studies have reported conformational changes of receptor and/or ligand and/or both that may alter their biological responses. Paige et al. ${ }^{66}$ revealed conformational changes in estrogen receptor by their relative changes in the affinity of the peptides. The binding of agonists to G-protein-coupled receptors is characterized by high- and lowaffinity binding states with active ternary and inactive binary complexes of the receptor. ${ }^{67}$ It has been suggested that a specific interaction between the third and the seventh transmembrane helixes may be a major determinant of $\mathrm{AT}_{1}$ receptor isomerization from an inactive to active conformation. ${ }^{68}$ Binding of $\alpha 5 \beta 1$ to urokinase-type plasminogen activator receptors causes a change in the conformation to block the functions of this complex by short $\beta 1$-chain peptides without affecting $\alpha 5 \beta 1$-mediated fibronectin binding. ${ }^{69}$ Therefore, the decoy peptide blunted the interaction of renin with $(\mathrm{P}) \mathrm{RR}$ possibly by changing specific space within the receptor.

\section{PERSPECTIVES}

The $(\mathrm{P}) \mathrm{RR}$ has replenished the interest of the investigators in the field of renin- and prorenin-angiotensin system that helped to shed light on the physiological role of prorenin. Many in vivo studies have demonstrated the role of non-proteolytic activation of prorenin mediated by the $(\mathrm{P}) \mathrm{RR}$ in the pathogenesis of diabetic nephropathy and retinopathy as well as in the activation of tissue specific RAS, which might lead to the onset of hypertension. The importance of the decoy peptide, a precursor sequence from the prorenin prosegment, for prorenin binding to (P)RR has been reported. Both in vivo and in vitro studies have demonstrated that this peptide inhibits nonproteolytic activation of prorenin by restricting the binding of prorenin to the receptor. Further studies may help to understand the counter part of decoy peptide present in (P)RR and its mode of action in blocking renin/prorenin binding to this receptor. Moreover, 'hinge' region peptide, a common sequence both in renin and prorenin, also indicate the plausible reason for the renin binding to $(\mathrm{P}) \mathrm{RR}$. This new peptide could also be a better blocker for the (P)RR to inhibit the binding of renin and prorenin to the $(\mathrm{P}) \mathrm{RR}$. More studies are needed to substantiate the fact that this 'hinge' region peptide, as a (P)RR blocker, can attenuate the pathological conditions by inhibiting the (P)RR-stimulated activation of renin and prorenin either in an angiotensin-II-dependent and/or -independent pathway in vivo. In addition, it is yet to be elucidated whether the decoy and 'hinge' peptides can bind to the recently reported shedded $(\mathrm{P}) \mathrm{RR}^{70}$ and thus attenuate the interaction of renin/prorenin with this receptor. Hence, using those peptides mimicking regions of the structures of renin and prorenin, it would be possible to explain comprehensively the detailed binding mechanisms of renin and prorenin to the $(\mathrm{P}) \mathrm{RR}$.

\section{ACKNOWLEDGEMENTS}

This study was supported in part by a Grant-in-aid for Scientific Research (1907165) from the Ministry of Education, Science. AHM Nurun Nabi is the recipient of a Postdoctoral Fellowship for Foreign Researchers (2007/2009: P07165) from Japan Society for the Promotion of Science.

1 Re RN. Cellular biology of the renin-angiotensin systems. Arch Intern Med 1984; 144: 2037-2041.

2 Frohlich ED, Iwata T, Sasaki O. Clinical and physiologic significance of local tissue renin-angiotensin systems. Am J Med 1989; 87: 19s-22s.

3 Lever AF. Renin: endocrine, paracrine, or part-paracrine control of blood pressure? Am J Hypertens 1989; 2: 276-285.

4 Campbell DJ. Extrarenal renin and blood pressure regulation: an alternative viewpoint. Am J Hypertens 1989; 2: 266-275.

5 Baxter JD, Perloff D, Hsueh W, Biglieri EG. The endocrinology of hypertension. In: Felig P, Baxter JD, Frohman LA (eds). Endocrinology and Metabolism, 3rd edn McGraw, McHill: New York, 1995 pp 749-853.

6 Lutterotti NV, Catanzaro DF, Sealey JE, Laragh JH. Renin is not synthesized by cardiac and extrarenal vascular tissues: a review of experimental evidence. Circulation 1994; 89: 458-470.

7 Krop M, Danser AH. Circulating versus tissue renin-angiotensin system: on the origin of (pro)renin. Curr Hypertens Rep 2008, 112-118.

8 Hsueh WA, Do YS, Wang PH. Observations on the renal processing and sorting of prorenin. Can J Physiol Pharmacol 1991; 69: 1327-1330.

9 Leckie BJ, Birnie G, Carachi R. Renin in Wilms' tumor: prorenin as an indicator. J Clin Endocrinol Metab 1994; 79: 1742-1746.

10 Luetsher JA, Kraemer FB, Wilson DM, Schwartz HC, Bryer-Ash M. Increased plasma inactive renin in diabetes mellitus. A marker of microvascular complications. $N$ Engl J Med 1985; 312: 1412-1417.

11 Inagami T. Purification of renin and prorenin. Hypertension 1991; 18: 241-251.

12 Morris BJ. Molecular biology of renin I: gene and protein structure, synthesis and processing. J Hypertens 1992; 10: 209-214.

13 Suzuki F, Tanaka N, Takeuchi K, Muramoto Y, Inagami T, Murakami K, Nakamura Y. Acid-activation of rat prorenin following non-proteolytic alteration. In: Takahashi K (ed). Aspartic Proteinases. Plenum Publishing Co.: New York, 1995 pp 267-272.

14 Baxter JD, James MN, Chu WN, Duncan K, Haidar MA, Carilli CT, Reudelhuber TL. The molecular biology of human renin and its gene. Yale J Biol Med 1989; 62: 493-501.

15 Heinrikson RL, Hui J, Zurcher-Neely H, Poorman RA. A structural model to explain the partial catalytic activity of human prorenin. Am J Hypertens 1989; 2: 367-380.

16 Carilli CT, Vigne JL, Wallace LC, Smith LM, Wong MA, Lewicki JA, Baxter JD. Characterization of recombinant human prorenin and renin. Hypertension 1988; 11: 713-716.

17 Wang PH, Do YS, Macaulay L, Shinagawa T, Anderson PW, Baxter JD, Hsueh WA. Identification of renal cathepsin $\mathrm{B}$ as a human prorenin-processing enzyme. J Biol Chem 1991; 266: 12633-12638.

18 Morris BJ. Activation of human inactive ('Pro') renin by cathepsin D and pepsin. J Clin Endocrinol Metab 1978; 46: 153-157.

19 Dzau VJ, Gonzalez D, Kaempfer C, Dubin D, Wintroub B. Human neutrophils release serine proteases capable of activating prorenin. Circ Res 1987; 60: 595-601.

20 Derkx FHM, Tan-Tjiong L, Veld AJM, Schalekamp MPA, Schalekamp MADH. Activation of inactive plasma renin by tissue kallikreins. J Clin Endocrinol Metab 1979; 49: 765-769.

21 Chantal M, Isabelle J, Robert D, Nabil GS, Timothy LR. Prohormone convertase PC5 is a candidate processing enzyme for prorenin in the human adrenal cortex. Hypertension 1996; 28: 840-846.

22 Morris BJ. Molecular biology of renin I: gene and protein structure, synthesis and processing. J Hypertens 1992; 10: 209-214.

23 Pitarresi TM, Rubattu S, Heinrikson R, Sealey JE. Reversible cryoactivation of recombinant human prorenin. J Biol Chem 1992; 267: 11753-11759.

24 Suzuki F, Hayakawa M, Nakagawa T, Uddin MN, Ebihara A, Iwasawa A, Ishida $Y$, Nakamura Y, Kazuo M. Human prorenin has 'gate and handle' regions for its non-proteolytic activation. J Biol Chem 2003; 278: 22217-22222.

25 Nguyen G, Delarue F, Burckle C, Bouzhir L, Giller T Sraer JD. Pivotal role of the renin/ prorenin receptor in angiotensin II production and cellular responses to renin. J Clin Invest 2002; 109: 1417-1427.

26 Nabi AHMN, Kageshima A, Uddin MN, Nakagawa T, Park EY, Suzuki F. Binding properties of rat prorenin and renin to the recombinant rat renin/prorenin receptor prepared by a baculovirus expression system. Int J Mol Med 2006; 18: 483-488.

27 Batenburg WW, Krop M, Garrelds IM, de Vries R, de Bruin RJ, Burcklé CA, Müller DN, Bader M, Nguyen G, Danser AH. Prorenin is the endogenous agonist of the (pro)renin receptor. Binding kinetics of renin and prorenin in rat vascular smooth muscle cells overexpressing the human (pro)renin receptor. J Hypertens 2007; 25: 2441-2453.

28 Zhang J, Noble NA, Border WA, Owens RT, Huang Y. Receptor-dependent prorenin activation and induction of PAl-1 expression in vascular smooth muscle cells. Am J Physiol Endocrinol Metab 2008; 295: E810-E819.

29 Nurun NA, Uddin MN, Nakagawa T, Iwata H, Ichihara A, Inagami T, Suzuki F. Role of 'handle' region of prorenin prosegment in the non-proteolytic activation of prorenin by binding to membrane anchored (pro)renin receptor. Front Biosci 2007; 12: 4810-4817 
30 Ichihara A, Hayashi M, Kaneshiro Y, Suzuki F, Nakagawa T, Tada Y, Koura Y, Nishiyama A, Okada H, Uddin MN, Nabi AHMN, Ishida $Y$, Inagami T, Saruta T. Inhibition of diabetic nephropathy by a decoy peptide corresponding to the 'handle' region for nonproteolytic activation of prorenin. J Clin Invest 2004; 114: 1128-1135.

31 Kaneshiro Y, Ichihara A, Sakoda M, Takemitsu T, Nabi AN, Uddin MN, Nakagawa T, Nishiyama A, Suzuki F, Inagami T, Itoh $\mathrm{H}$. Slowly progressive, angiotensin II-independent glomerulosclerosis in human renin/prorenin receptor transgenic rats. J Am Soc Nephrol 2007; 18: 1789-1795.

32 Burckle CA, Jan Danser AH, Muller DN, Garrelds IM, Gasc JM, Popova E, Plehm R, Peters J, Bader M, Nguyen G. Elevated blood pressure and heart rate in human renin receptor transgenic rats. Hypertension 2006; 47: 1-5.

33 Ichihara A, Sakoda M, Kurauchi-Mito A, Kaneshiro Y, Itoh H. Involvement of (pro)renin receptor in the glomerular filtration barrier. J Mol Med 2008; 86: 629-635.

34 Ichihara A, Sakoda M, Mito-Kurauchi A, Itoh H. Activated prorenin as a therapeutic target for diabetic nephropathy. Diab Res Clin Prac 2008; 82: S63-S66.

35 Ichihara A, Sakoda M, Kurauchi-Mito A, Kaneshiro Y, Itoh H. Renin, prorenin and the kidney: a new chapter in an old saga. J Nephrol 2009; 22: 306-311.

36 Danser AHJ, van Kats JP, Admiraal PJJ, Derkx FHM, Lamers JMJ, Verdouw PD, Saxena $\mathrm{PR}$, Schalekamp MADH. Cardiac renin and angiotensins. Uptake from plasma versus in situ synthesis. Hypertension 1994; 24: 37-48.

37 Katz SA, Opsahl JA, Lunzer MM, Forbis LM, Hirsch AT. Effect of bilateral nephrectomy on active renin, angiotensinogen, and renin glycoforms in plasma and myocardium. Hypertension 1997; 30: 259-266.

38 Feldt S, Batenburg WW, Mazak I, Maschke U, Wellner M, Kvakan $H$, Dechend $R$, Fiebeler A, Burckle C, Contrepas A, Danser AHJ, Bader M, Nguyen G, Luft FC, Muller DN. Prorenin and renin-induced extracellular signal-regulated kinase $1 / 2$ activation in monocytes is not blocked by aliskiren or the handle-region peptide. Hypertension 2008; 51: 682-688.

39 Huang Y, Wongamorntham S, Kasting J, McQuillan D, Owens RT, Yu L, Noble NA, Border W. Renin increases mesangial cell transforming growth factor-betal and matrix proteins through receptor-mediated, angiotensin II-independent mechanisms. Kidney Int 2006; 69: 105-113.

40 Saris JJ, t Hoen PA, Garrelds IM, Dekkers DH, den Dunnen JT, Lamers JM, Jan Danser $\mathrm{AH}$. Prorenin induces intracellular signalling in cardiomyocytes independently of angiotensin II. Hypertension 2006; 48: 564-571.

41 Sakoda M, Ichihara A, Kaneshiro Y, Takemitsu T, Nakazato Y, Nabi AH, Nakagawa T, Suzuki F, Inagami T, Itoh H. (Pro)renin receptor-mediated activation of mitogenactivated protein kinases in human vascular smooth muscle cells. Hypertens Res 2007; 30: 1139-1146.

42 Schefe JH, Menk M, Reinemund J, Effertz K, Hobbs RM, Pandolfi PP, Ruiz P, Unger T, Funke-Kaiser $\mathrm{H}$. A novel signal transduction cascade involving direct physical interaction of the renin/prorenin receptor with the transcription factor promyelocytic zinc finger protein. Circ Res 2006; 99: 1155-1166.

43 Suzuki F. Non-proteolytic activation of prorenin by the (pro)renin receptor is blocked by decoy peptide. J Renin Angiotensin Aldosterone Syst 2007; 8: 101-103.

44 Nabi AHMN, Biswas KB, Nakagawa T, Ichihara A, Inagami T, Suzuki F. Decoy peptide region (RIFLKRMPSI) of prorenin prosegment plays a crucial role in prorenin binding to the (pro)renin receptor. Int J Mol Med 2009; 24: 83-89.

45 Nabi AHMN, Biswas KB, Nakagawa T, Ichihara A, Inagami T, Suzuki F. Prorenin has high affinity multiple binding sites for (pro)renin receptor. Biochim Biophys Acta 2009; 1794: 1838-1847.

46 Takahashi H, Ichihara A, Kaneshiro Y, Inomata K, Sakoda M, Takemitsu T, Nishiyama A, Itoh $\mathrm{H}$. Regression of nephropathy developed in diabetes by (Pro)renin receptor blockade. J Am Soc Nephrol 2007; 18: 2054-2061.

47 Ichihara A, Kaneshiro Y, Takemitsu T, Sakoda M, Nakagawa T, Nishiyama A, Kawachi H, Shimizu F, Inagami T. Contribution of non-proteolytically activated prorenin in glomeruli to hypertensive renal damage. J Am Soc Nephrol 2006; 17: 2495-2503.

48 Ichihara A, Kaneshiro Y, Takemitsu T, Sakoda M, Suzuki F, Nakagawa T, Nishiyama A, Inagami T, Hayashi M. Nonproteolytic activation of prorenin contributes to development of cardiac fibrosis in genetic hypertension. Hypertension 2006; 47: 894-900.

49 Shan Z, Cuadra AE, Sumners C, Raizada MK. Characterization of a functional (pro)renin receptor in rat brain neurons. Exp Physiol 2008; 93: 701-708.

50 Susic D, Zhou X, Frohlich ED, Lippton H, Knight M. Cardiovascular effects of prorenin blockade in genetically hypertensive rats (SHR) on normal and high salt diet. $\mathrm{Am} \mathrm{J}$ Physiol Heart circ Physiol 2008; 295: H1117-H1121.
51 He M, Zhang L, Shao Y, Wang X, Huang Y, Yao T, Lu L. Inhibition of renin/prorenin receptor attenuated mesangial cell proliferation and reduced associated fibrotic factor release. Eur J Pharmacol 2009; 606: 155-161.

52 Yokota H, Takamiya A, Nagaoka T, Kitaya N, Mori F, Hikichi T, Yoshida A, Ishida Y, Suzuki F. A peptide corresponding to handle region for nonproteolytic activation of prorenin inhibits retinal neovascularization in a retinopathy of prematurity model. Invest Ophthalmol Vis Sci 2005; 46 E-Abstract 4108.

53 Satofuka S, Ichihara A, Nagai N, Koto T, Shinoda H, Noda K, Ozawa Y, Inoue M, Tsubota $\mathrm{K}$, Itoh $\mathrm{H}$, Oike $\mathrm{Y}$, Ishida S. Role of nonproteolytically activated prorenin in pathologic, but not physiologic, retinal neovascularization. Invest Ophthalmol Vis Sci 2007; 48: 422-429.

54 Satofuka S, Ichihara A, Nagai N, Yamashiro K, Koto T, Shinoda H, Noda K, Ozawa Y, Inoue M, Tsubota K, Suzuki F, Oike Y, Ishida S. Suppression of ocular inflammation in endotoxin-induced uveitis by inhibiting nonproteolytic activation of prorenin. Invest Ophthalmol Vis Sci 2006; 47: 2686-2692.

55 Muller DN, Klanke B, Feldt S, Cordasic N, Hartner A, Schmieder RE, Luft FC, Hilgers KF. (Pro)renin receptor peptide inhibitor 'handle-region' peptide does not affect hypertensive nephrosclerosis in Goldblatt rats. Hypertension 2008; 51: 676-681.

56 Mercure C, Prescott G, Lacombe MJ, Silversides DW, Reudelhuber TL. Chronic increases in circulating prorenin are not associated with renal or cardiac pathologies. Hypertension 2009; 53: 1062-1069.

57 Wood JM, Maibaum J, Rahuel J, Grütter MG, Cohen NC, Rasetti V, Rüger H, Göschke R, Stutz S, Fuhrer W, Schilling W, Rigollier P, Yamaguchi Y, Cumin F, Baum HP, Schnell CR, Herold P, Mah R, Jensen C, O'Brien E, Stanton A, Bedigian MP. Structure-based design of aliskiren, a novel orally effective renin inhibitor. Biochem Biophys Res Commun 2003; 308: 698-705.

58 Jensen C, Herold P, Brunner HR. Aliskiren: the first renin inhibitor for clinical treatment. Nat Rev Drug Discov 2008; 7: 399-410.

59 Trimarchi H, Orias M. Aliskiren and the kidney: beyond hypertension. Nephrol Rev 2009; 1: 1-4.

60 Krop M, Garrelds IM, de Bruin RJA, van Gool JMG, Fisher NDL, Hollenberg NK, Danser AHJ. Aliskiren accumulates in renin secretory granules and binds plasma prorenin. Hypertension 2008; 52: 1076-1083.

61 Feldman DL, Jin L, Xuan H, Contrepas A, Zhou Y, Webb RL, Mueller DN, Feldt S, Cumin F, Maniara W, Persohn E, Schuetz H, Jan Danser AH, Nguyen G. Effects of aliskiren on blood pressure, albuminuria, and (pro)renin receptor expression in diabetic TG(mRen2) 27 rats. Hypertension 2008; 52: 130-136.

62 Szelke M, Leckie B, Hallett A, Jones DM, Sueiras J, Atrash B, Lever AF. Potent new inhibitors of human renin. Nature 1982; 299: 555-557.

63 Dunn BM, Deyrup C, Moesching WG, Gilbert WA, Nolan RJ, Trach ML. Inhibition of pepsin by zymogen activation fragments. Spectrum of peptides released from pepsinogen $\mathrm{NH} 2$ terminus and solid phase synthesis of two inhibitory peptide sequences. J Biol Chem 1978; 253: 7269-7275.

64 Harboe M, Andersen PM, Foltman B, Kay J, Kassell B. The activation of bovine pepsinogen. Sequence of the peptides released, identification of a pepsin inhibitor. J Biol Chem 1974; 249: 4487-4494.

65 Cumin F, Evin G, Fehrentz JA, Seyer R, Castro B, Menard I, Corvol P. Inhibition of human renin by synthetic peptides derived from its prosegment. J Biol Chem 1985; 260: 9154-9157.

66 Paige LA, Christensen DJ, Grøn H, Norris JD, Gottlin EB, Padilla KM, Chang C, Ballas LM, Hamilton PT, Mcdonnell DP, Fowlkes D. Estrogen receptor (ER) modulators each induce distinct conformational changes in ER $\alpha$ and ER $\beta$. Proc Natl Acad Sci USA 1999; 96: 3999-4004.

67 De Lean A, Stadel JM, Lefkowitz RJ. A ternary complex model explains the agonistspecific binding properties of the adenylate cyclase-coupled beta-adrenergic receptor. J Biol Chem 1980; 255: 7108-7117.

68 Balmforth AJ, Lee AIJ, Warburton P, Donnelly D, Ball SG. The Conformational change responsible for $\mathrm{AT}_{1}$ receptor activation is dependent upon two juxtaposed asparagine residues on transmembrane helices III and VII. J Cell Biol 1997; 272: 4245-4251.

69 Wei Y, Czekay RP, Robillard L, Kugler MC, Zhang F, Kim KK, Xiong J, Humphries MJ, Chapman HA. Regulation of $\alpha 5 \beta 1$ integrin conformation and function by urokinase receptor binding. J Cell Biol 2005; 168: 501-511.

70 Cousin C, Bracquart D, Contrepas A, Corvol P, Muller L, Nguyen G. Soluble form of the (pro)renin receptor generated by intracellular cleavage by furin is secreted in plasma. Hypertension 2009; 53: 1077-1082. 